\title{
ブレードビットとコーンビットの掘さく作用の比較
}

\author{
藤 井 清 光*・佐 藤 光 夫* \\ (昭和44年 1 月 30 日受理)
}

\section{Penetration Effects of Blade Bit and a Cone Bit}

by

Kiyomitsu FuJII and Mitsuo SATo

\begin{abstract}
Acstract By the use of a laboratory drilling equipment the penetration effects of both a blade bit and a cone bit were measured under atmospheric pressure. In this study a $33 / 4$ in-three wing blade bit and a $33 / 4$ in-three cone soft type bit were tested. As rock samples soft andesite and tuff were used. In drilling tests with same bit load and rotary speed the penetration rate of a blade bit was as great as twice as that of a cone bit. To obtain a similar penetration rate of a cone bit, a blade bit needed the reduced load of $60-66 \%$ of that given to a cone bit. As a result of analyses of grain size distribution of cuttings, greater grain size was obtained at a lower rotary speed in a test with a cone bit: on the contrary to this, there was no obvious relationship between grain size and rotary speed in a test with a blade bit.
\end{abstract}

\section{1. 研 究目的}

最近では石油または天然ガス井の掘さくには，ほとん ぞコーンビットが使われ，ブレードビットの使用はごく わずかである。しかし一般には，ロータリー掘さくに使 われるビットはブレード型とロックビットに分類され る。そしてブレード型は軟らかい地層の掘さくに威力を 発揮し, 特に価格の点で有利である。一方, 土木関係の 掘さくにはブレードビットが主として使われ，ロックビ ットの使用は例外に属する。さらに非常に硬い地層に対 してはロックビットは不適当であって, ダイヤモンドビ ットまたはメタルクラウンビットが使われる。以上のこ とはロータリー掘さくに対してロックビット（特にコー ンビット）が万能でなく, ブレードビットの存在を無視 することができないことを意味する。

この研究はブレードビットとコーンビットの掘さく作 用を実験によって明らかにして，両者の特色を比較する ことを目的とする。コーンビットの掘さく作用に関して

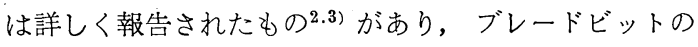
掘さく作用に関しても報告された ${ }^{11}$ 。それで今回は各ビ

* 東京大学工学部資源開発 (石油) 工学科
ットの掘さく作用の詳しい説明を省略し、両者の比較の みについて記すことにする。

\section{2. 実 験 方 法}

\section{1 装置}

実験装置は参考文献2)と同じであるが，装置の一部を 改善した。すなわち小さい荷重をビットに与える場合は 油圧シリンダーを使わず，テコと“和もり”による荷重 を与えるように改善した。この研究では, 主としてこの 方法でビットに荷重が与えられた。循環流体としては清 水が使われ，その流量はカッティングを完全に除去しう るようにした。

ビットの変位は最高 $70 \mathrm{~mm}$ まで測定可能であり, 荷 重は最高約 $5 \mathrm{t}$, トルクは最高 $40 \mathrm{~kg} ・ \mathrm{~m}$ まで測定可能で あり，各測定值の周波数は約 $300 \mathrm{c} / \mathrm{s}$ まで測定できる計 測器が使用された。な抏,ビットの回転数は $22 \sim 165 \mathrm{rpm}$ の範囲で 9 段切りかえが可能である。

\section{2 ビット}

実験に使われたビットは写真に示されているような 3 枚刃ブレードビット（直径 $33 / 4$ in）打よび軟質用の 3 コーンビット(直径 $33 / 4$ in) である。な损, ブレード 
写真 使用したビット

$$
\text { コーンビットブレードビット }
$$
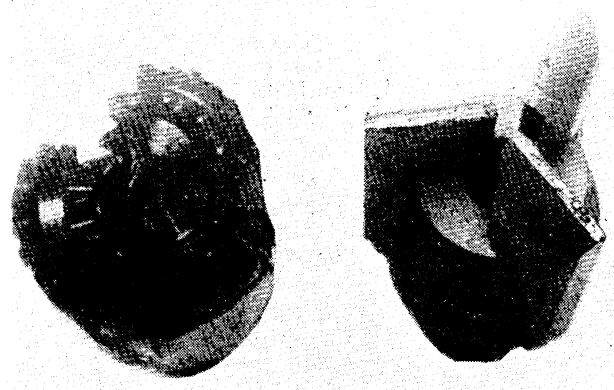

ビット刃の先が石に接蝕する部分は $42 \mathrm{~mm} \times 4 \mathrm{~mm} \times 3$ 個である。カッティング除去の条件を同じとするため, 泥水噴出口の形はともにレギュラ一型である。実験に使 用されたビットのす法は第 1 表に示されている。

第 1 表 ビットの寸法

\begin{tabular}{|c|c|c|c|c|}
\hline & 直 $\begin{array}{c}\text { 径 } \\
\text { in }\end{array}$ & 型 式 & $\begin{array}{l}\text { 泥水噴出 } \\
\text { 口 } \\
\text { 直径 } \mathrm{mm}\end{array}$ & その他 \\
\hline ブレードビット & $33 / 495$ & 3 枚刃 & 25 & $\begin{array}{c}\text { 刃の長さ } \\
42 \mathrm{~mm} \text {, } \\
\text { 幅 } 4 \mathrm{~mm}\end{array}$ \\
\hline コーンビット & $3 \quad 3 / 495$ & 3 コーン & 20 & $\begin{array}{l}\text { オフセッ } \\
\text { 卜角度 } 4^{\circ}\end{array}$ \\
\hline
\end{tabular}

\section{3 石の試料}

掘さくに使用された石は白河石（安山岩）扣よび青石 (凝灰岩) である。その物理的性質は第 2 表に示されて いる。水に濡れた状態扣よび水に飽和された状態におい ても測定された。掘さくには水が使用されたので，石の 性質は水に接触した状態のものを使用すべきである。な 扣, 強度測定の場合の試料の寸法は直径は $30 \mathrm{~mm}$ で, 長さは圧縮試験の場合は $60 \mathrm{~mm}$, 圧裂試験の場合は 15 $\mathrm{mm}$ であった。

第 2 表 石の強度 $\mathrm{kg} / \mathrm{cm}^{2}$

\begin{tabular}{|c|c|c|c|c|}
\hline & \multicolumn{2}{|c|}{ 白河石 (妿山岩) } & \multicolumn{2}{|c|}{ 青 石（凝灰岩） } \\
\hline & 压縮強度 & 生裂強度 & 压縮強度 & 压裂強度 \\
\hline 乾 燥 状 態 & 400 & 28 & 380 & 53 \\
\hline 水に濡れた状態 & 280 & 24 & 219 & 30 \\
\hline 水飽和 状態 & 270 & 21 & 150 & 22 \\
\hline
\end{tabular}

\section{3. 測 定 結 果}

\section{1 測定記録に表われた特色}

ブレードビットとコーンビットの掘さく作用の特色を
第 1 図より知ることができる。これは白河石に対し1.07 〜 $1.17 \mathrm{t}$ の荷重, 扣よび $22 \mathrm{rpm}$ の回転を与えて掘さく したものである。この図で横軸はビットの掘進時間であ り, 縦軸は上よりビットの変位, トルク扣よび荷重を示 す。まず変位の変化は，ブレードビットでは非常になめ らかであるのに対し、コーンビットは上下の変動があ る。その理由は, ブレードビットの刃先は常に石に密着 しているのに対し，コーンビットは (文献2)に示すよう に), コーンの回転によりビット全体が上下に動くから である。したがってブレードビットを使用すれば，ドリ ルパイプに振動というわるい影響を与えるのを防ぐこと ができる。変位の変動は石が受ける荷重に影響を与え る。すなわちブレードビットでは荷重の変動はわずかで あるが，コーンビットでは荷重の変動が大きい。この理 由はブレードビットは静荷重のみ受けるのに対し, コー ンビットは静荷重のほかにビットの上下運動による動荷 重が加わるからである。

トルクに関しても両者には差がある。コーンビットに 抒けるトルクの変化は（この測定では） 1 秒間に 7 ～10 回程度であるが，ブレードビットのトルクはこれよりは るかに多く変化している。このような差はビットの掘さ く作用の違いより生ずる。すなわちブレードビットは刃 先が石を（ほとんど）水平にけずりながら回転するのに 対し、コーンビットでは刃先は“石をこじる作用”をな し，これにビット全体の上下運動が加わる。その結果, コーンビットよりブレードビットの方がはるかに大きな トルクを示す。

以上のように，第 1 図はブレードビットとコーンビッ トの掘さく作用の本質的な違いをはっきり示している。

\section{2 荷重・回転と掘進速度の関係}

ビットに与える荷重とビットの掘進速度の関係を示し たものが第 2 図（白河石を使用）扣よび第 3 図（青石を 使用）である。な打，回転数は 22,99 打よび $165 \mathrm{rpm}$ となっている。一定回転数に扣ける荷重と掘進速度の関 係は, 両種類のビットとも同じ傾向を示している。しか し一定荷重・一定回転数に扣ける掘進速度を比較する と,ブレードビットはコーンビットの約 2 倍になってい る。このことは従来見落されていた重要なことである。 不の性質が第 2 表の程度の場合には, ブレードビットを 使用して掘さくする方がはるかに有利であることを，こ れらの図は示している。これらの図は同じ掘進速度を得 るには,ブレードビットはコーンビットより小さい荷重 でよいことを示している。すなわちブレードビットに与 える荷重は，コーンビットの場合の 60～66\% にすれば 両者の掘進速度は同じになる。多数のドリルカラーを使 うことは困難なことが多いが，ブレードビットを使用す 
第 1 図 掘進時間と测定結果の関係一ブレードビットとコ ーンビットの比較 (22rpm, 白河石)

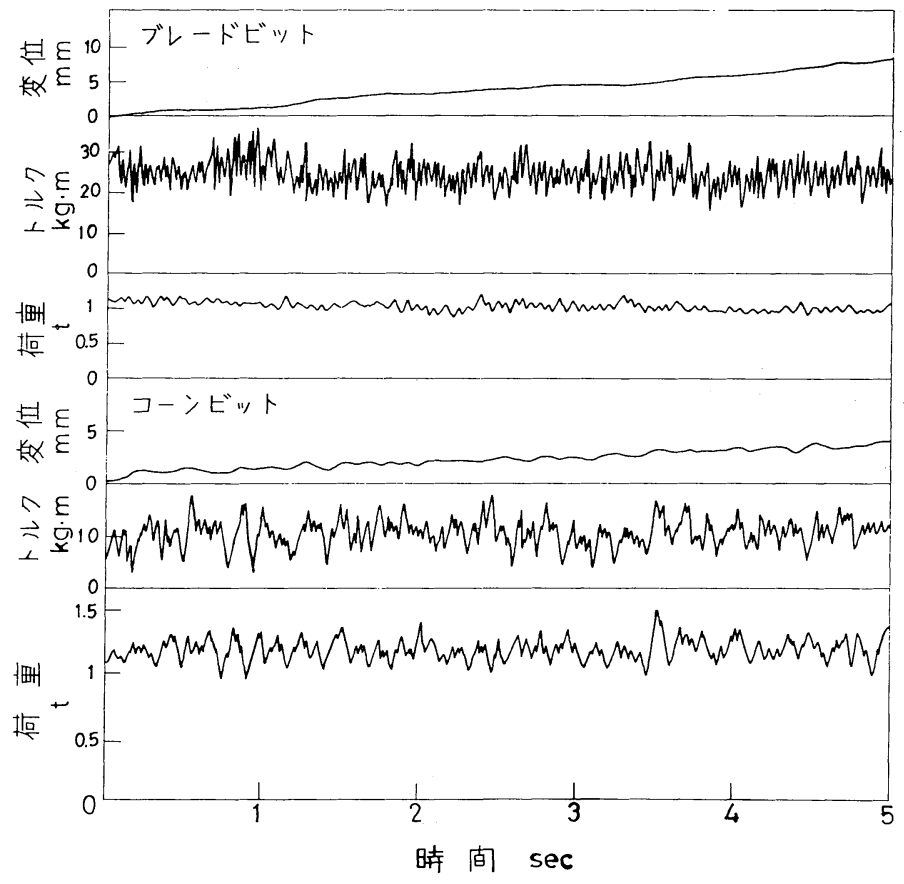

第 2 図荷重と掘進速度の関係（白河石）

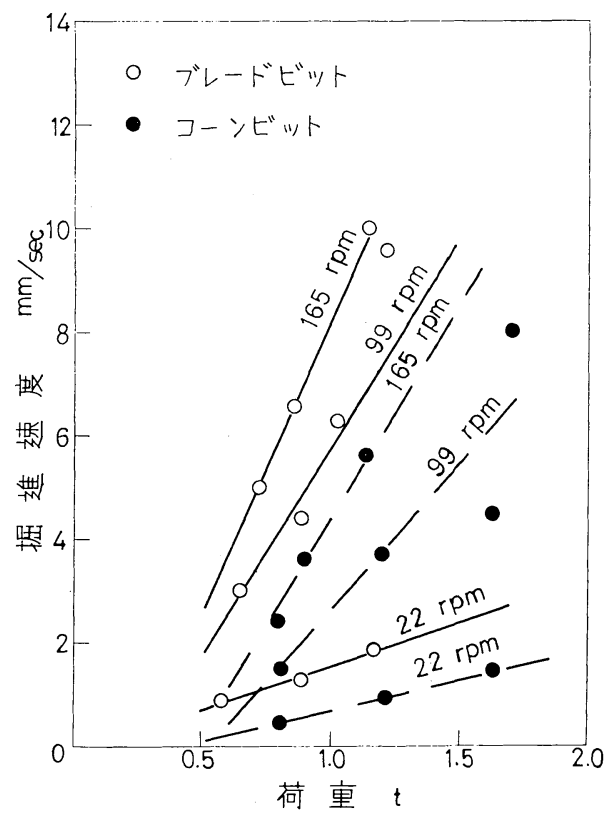

第 3 図 荷重と掘進速度の関係（青石）

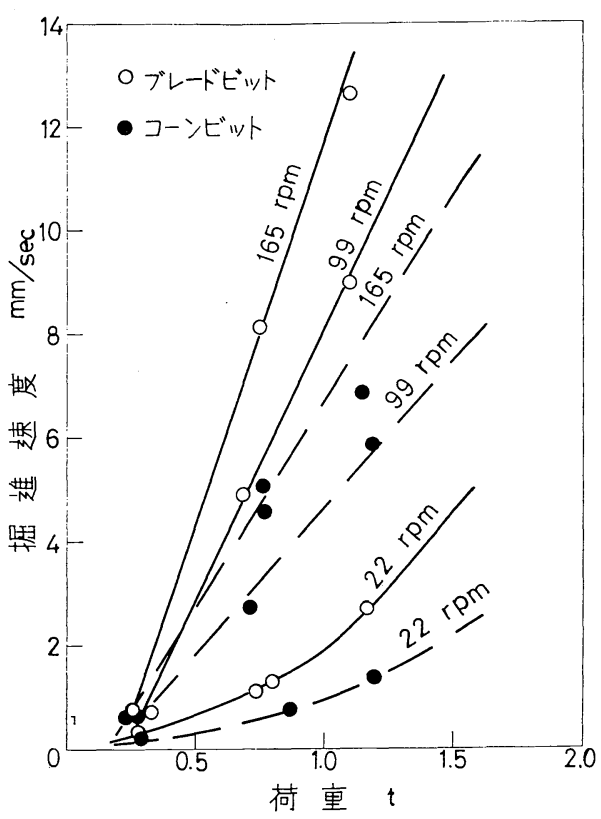


第 4 図 回転数と掘進速度の関係（白河石）

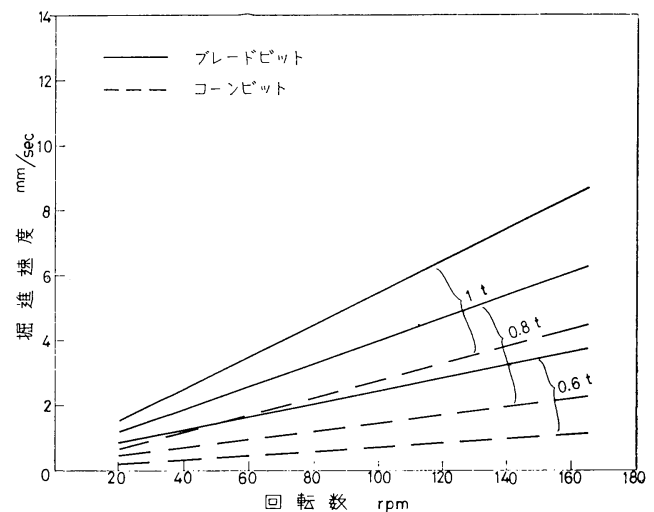

第 5 図回転数と掘進速度の関係（青石）

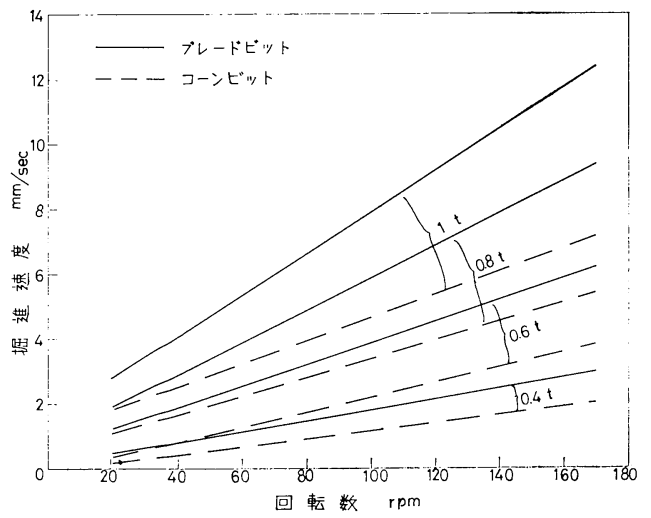

ればドリルカラーは少なくてよく，経済的に有利であ る。

以上の実験結果を整理し直し，横軸に回転数をとって 表わしたものが第 4 〜図である。すなわち第 2 図より 第 4 図を求め, 第 3 図より第 5 図を求めた。このように 整理し直しても，2種類のビットの掘さく状態は全く同 じ傾向を示す。

\section{3 トルクと荷重の関係}

ビットに対する荷重の増加はビットに㧊けるトルクの 増加となる。第 6 図はこれを示して扣り,さらにこの図 より次のことが理解できる。

（1）荷重とトルクは直線的な関係にある。

（2）コーンビットの場合よりブレードビットの場合 の方がはるかに大きなトルク（2.4～3.0倍）とな る。

（3）ブレードビットではトルクは石によって差がな いが，コーンビットでは白河石に打けるトルクよ り青石に打けるトルクが大きい。
第 6 図 荷重とトルクの関係

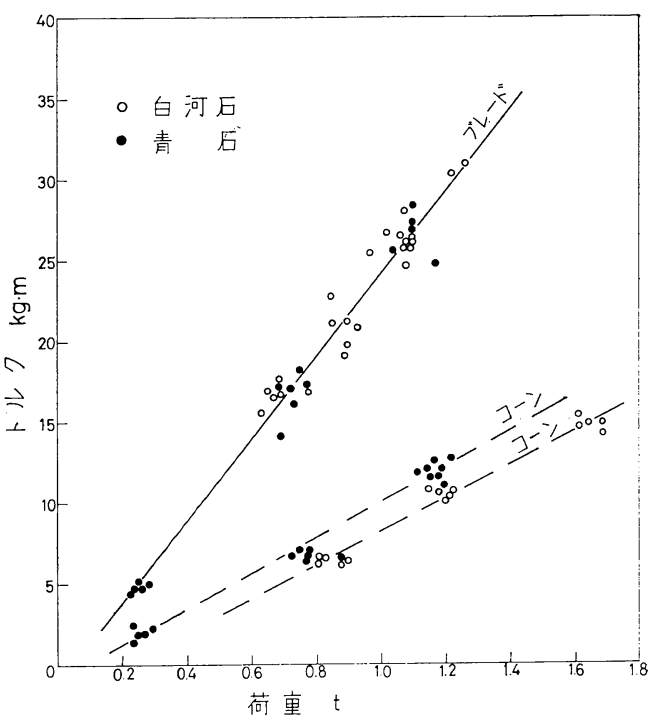

同じ荷重では両種類のビットでトルクに大きな差があ るが，ブレードビットの方が掘さく効率がはるかに大き いので，このような差が出ると見ることもできる。同じ 掘進速度では, ブレードビットのトルクはコーンビット のトルクの $1.2 \sim 1.5$ 倍程度であって, 両者の差は小さ い。

\section{4 カッティングの粒度分析}

ビットの掘さく作用を知る一つの方法として, ビット によって砕かれたもの，すなわちカッティングの粒度を 調べる方法がある。一般に大きな精のカッティングを生 ずる掘さく方法は，小さなものを生ずる場合より高い掘 さく効率を示すということができる。実験に扔いては, 掘さくによって生じたすべてのカッティングを集め, 水 で濡れた状態でらるい分けをし，乾燥し秤量したもので ある。このような分析結果は第 $7 \sim 12$ 図に示されてい る。

まず，第 7 図（ブレードビット）と第 8 図（コーンビ ット）は粒度に対する荷重の影響を示す。これは白河石 を使用して $99 \mathrm{rpm}$ に扔いて荷重を変えて掘さくした場 合を示す。これによればブレードビットでは，大きな荷 重ほど大きな粒のカッティングを生ずることが明らかで あるが，コーンビットではこのことは顕著でない。な 扣，この傾向は青石を使った実験に扣いても同じように 表われている（実験結果を省く）。

次に第 9 図（ブレードビット）と第10図コーンビット は，粒度に対する回䎐数の影響を示す。すなわち青石を 使用して，一定荷重に打いて回転数を変えて掘さくした 場合を示す。これによれば，上の場合と逆に，ブレード 
第 7 図 荷重とカッティング粒度の関係ーブレ ードビット (99rpm, 白河石)

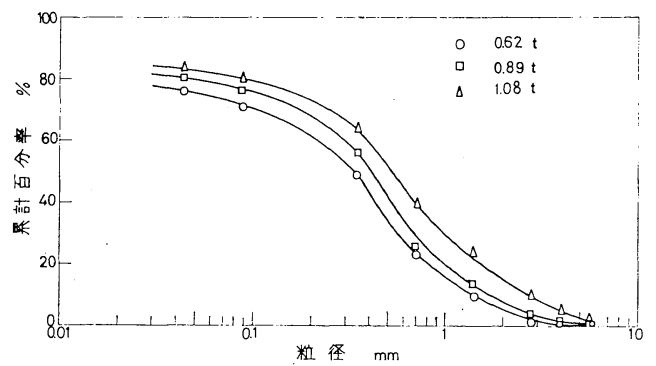

第 8 図荷重とカッティング粒度の関係ーコー ンビット (99rpm, 白河石)

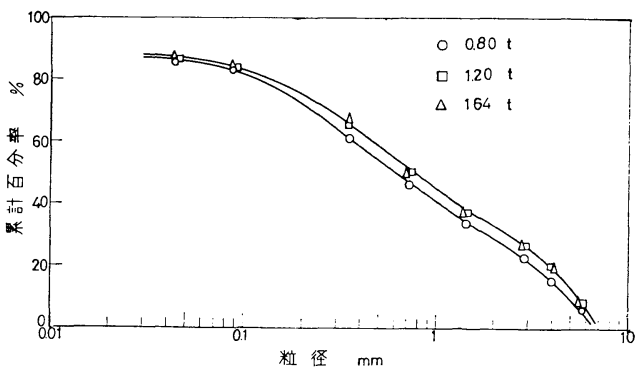

第 9 図回転数とカッティング粒度の関係 一ブレードビット（荷重 $0.68 \sim 0$. $75 \mathrm{t}$, 青石)

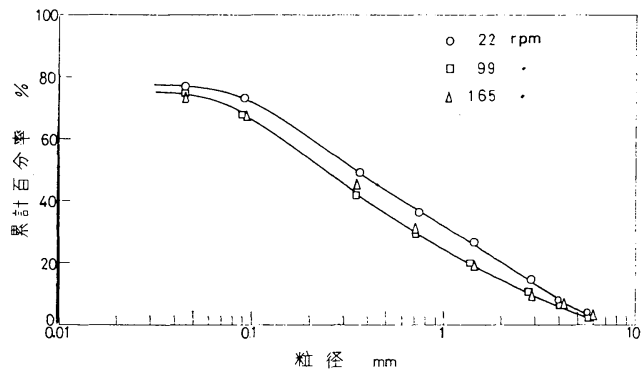

第10図 回転数とカッティング粒度と関係一コ ーンビット（荷重 $0.72 \sim 0.88 \mathrm{t}$, 青石)

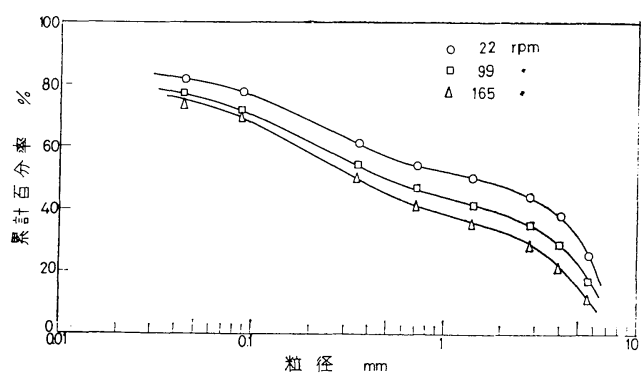

第11図カッティング粒度の比較（荷重0.80〜 $0.89 \mathrm{t}, 99 \mathrm{rpm}$ ，白河石）

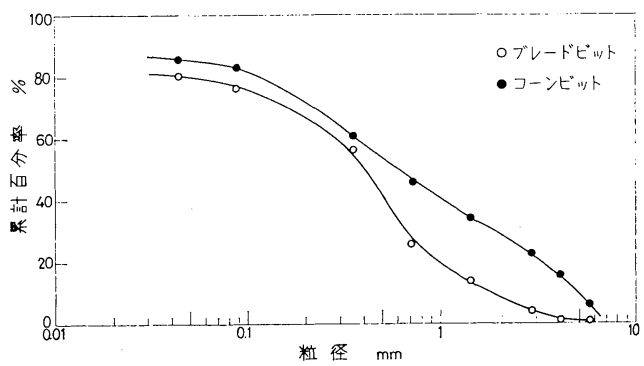

第12図 カッティング粒度の比較（荷重1.10 1. $17 \mathrm{t}, 99 \mathrm{rpm}$, 青石)

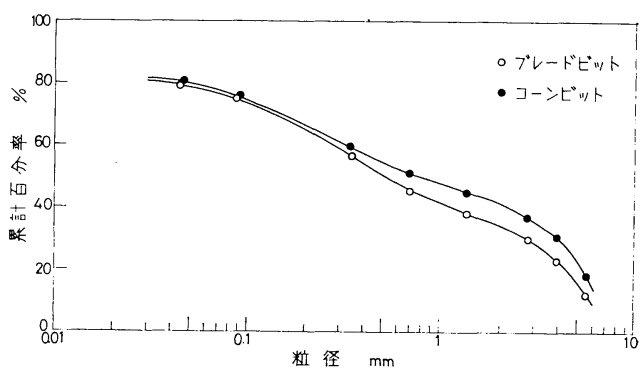

ビットでは，小さな回転数に扣いて大きな粒のカッティ ングを生ずることが明らかでないが，コーンビットで は，非常に明らかである（な㧪，この測定ではリカッテ ィングが生じないほぼ十分に水を循環したと考えられ る。)。こことはコーンビットの掘さく作用は, 回転数 に直接に関係することを示すりのであって，重要なこと である。な扣，青石を使った以上の実験の傾向は，白河 石を使った場合にも同じょうに表われている（実験結果 を省く)。

同じ掘さく条件に扔いて粒度を比較したものが第11図 （白河石）と第12図（青石）である。ともにコーンビッ トの方が，ブレードビットより大きな粒のカッティング を生ずることを示す。

\section{4. 結論}

ブレードビットとコーンビットの掘さく作用を比較す る目的で実験的研究を行ない，以下のような結論を得 た。

（1）ブレードビットはコーンビットに比べて，変位 の変動扣よび石に与える荷重の変動が小さいが，トルク は大きい。

（2）一定荷重・一定回転数に损いては，ブレードビ ットの掘進速度はコーンビットの掘進速度の約 2 倍であ 
る。

（3）同じ掘進速度を得るには，ブレードビットに与 える荷重はコーンビットに与える荷重の $60 ６ 6 \%$ でよ w。

（4）一定荷重に拈けるトルクは，ブレードビットの 場合はコーンビットの場合の $2.4 \sim 3.0$ 倍となる。

（5）同じ掘進速度となるためのトルクは, ブレード ビットの場合はコーンビットの場合の $1.2 \sim 1.5$ 倍とな る。

（6）カッティングの粒度分析の結果によれば，ブレ ードビットでは大きな荷重で大きな粒を生ずるが，回䎐
数の影響は小さい。これに反しコーンビットでは，小さ な回転数で明らかに大きな粒を生ずる。このことは 2 種 類のビットの掘さく作用の差が原因である。

\section{参 考 文 献}

1) 藤井清光：ブレードビットの掘さく作用に関する 基礎的研究，石技誌 21 巻 5 号，昭和 31 年 9 月

2) 藤井清光：ロータリービットの掘さく作用に関す る測定 (第 1 報)，石技誌 33 巻 5 号，昭和 43 年 5 月

3）藤井清光：同上（第 2 報），石技誌 34 巻 2 号，昭 和 44 年 3 月 